\title{
Review of: "The Intriguing Role of TLR Accessory Molecules in Cardiovascular Health and Disease"
}

\author{
Maximiliano J Jiménez-Dalmaroni ${ }^{1}$
}

1 Universidad Nacional de La Plata

Potential competing interests: The author(s) declared that no potential competing interests exist.

This review raises the central question of the role of TLRs accesory molecules in cardiovascular diseases. It is wellorganized beginning with a brief introduction about TLRs (signaling, ligands and their accesory molecules) and then it focused exclusively on the surface accesory molecules of TLRs. The only issue that I could raise is that in this review it is not described the role of soluble CD36 in the section of CD36 which has been described its presence in human plasma (1) and could modulate inflammation in the same way as soluble CD14 (2). Finally, I completely agree that a novel therapeutics for COVID-19 will be the design of inhibitors that binds TLR2 (3) with the aim of preventing coagulation and other cardiovascular diseases caused by the pro-inflammatory activation of TLR2 by the spike of SARS-CoV-2.

\section{References}

1 Plasma sCD36 is associated with markers of atherosclerosis, insulin resistance and fatty liver in a nondiabetic healthy population.

Handberg A, Højlund K, Gastaldelli A, Flyvbjerg A, Dekker JM, Petrie J, Piatti P, Beck-Nielsen H; RISC Investigators.J Intern Med. 2012 Mar;271(3):294-304. doi: 10.1111/j.1365-2796.2011.02442.x.

2 Soluble CD36 ectodomain binds negatively charged diacylglycerol ligands and acts as a co-receptor for TLR2. Jimenez-Dalmaroni MJ, Xiao N, Corper AL, Verdino P, Ainge GD, Larsen DS, Painter GF, Rudd PM, Dwek RA, Hoebe K, Beutler B, Wilson IA.PLoS One. 2009 Oct 22;4(10):e7411. doi: 10.1371/journal.pone.0007411.

3 Soluble human TLR2 ectodomain binds diacylglycerol from microbial lipopeptides and glycolipids.

Jiménez-Dalmaroni MJ, Radcliffe CM, Harvey DJ, Wormald MR, Verdino P, Ainge GD, Larsen DS, Painter GF, Ulevitch R, Beutler B, Rudd PM, Dwek RA, Wilson IA.Innate Immun. 2015 Feb;21(2):175-93. doi: 10.1177/1753425914524077. 